\title{
Learning on human resources management in the radiology residency program*
}

\author{
O aprendizado sobre gestão de recursos humanos no programa de residência em radiologia
}

\section{Aparecido Ferreira de Oliveira ${ }^{1}$, Henrique Manoel Lederman ${ }^{2}$, Nildo Alves Batista ${ }^{2}$}

Oliveira AF, Lederman HM, Batista NA. Learning on human resources management in the radiology residency program. Radiol Bras. 2014 Mar/Abr; 47(2):94-98.

Abstract Objective: To investigate the process of learning on human resource management in the radiology residency program at Escola Paulista de Medicina - Universidade Federal de São Paulo, aiming at improving radiologists' education.

Materials and Methods: Exploratory study with a quantitative and qualitative approach developed with the faculty staff, preceptors and residents of the program, utilizing a Likert questionnaire (46), taped interviews (18), and categorization based on thematic analysis.

Results: According to $71 \%$ of the participants, residents have clarity about their role in the development of their activities, and $48 \%$ said that residents have no opportunity to learn how to manage their work in a multidisciplinary team.

Conclusion: Isolation at medical records room, little interactivity between sectors with diversified and fixed activities, absence of a previous culture and lack of a training program on human resources management may interfere in the development of skills for the residents' practice. There is a need to review objectives of the medical residency in the field of radiology, incorporating, whenever possible, the commitment to the training of skills related to human resources management thus widening the scope of abilities of the future radiologists. Keywords: Medical education; Medical residency; Health personnel management; Radiology; Imaging diagnosis.

Resu mo Objetivo: Investigar a aprendizagem sobre gestão de recursos humanos na residência em radiologia da Escola Paulista de Medicina Universidade Federal de São Paulo, procurando aprimoramento da formação do radiologista.

Materiais e Métodos: Pesquisa exploratória, quantitativa e qualitativa, junto aos docentes, preceptores e residentes do programa, utilizando-se questionários no formato Likert (46) e aprofundamento com entrevistas (18) com categorização por análise temática.

Resultados: Para 71\% dos participantes, o residente tem clareza sobre o grau de autonomia e complexidade na realização das suas funções. Cinquenta e três por cento discordam que todos os profissionais envolvidos têm clareza de seus papéis no desenvolvimento das atividades e $48 \%$ afirmam que o residente não tem a oportunidade de aprender a gerir o trabalho em equipe multiprofissional.

Conclusão: $O$ isolamento nas salas de laudos, a pouca interatividade entre os setores com atividades diversificadas e estanques, a ausência de cultura prévia e a falta de ênfase do ensino na gestão de recursos humanos podem interferir no desenvolvimento de competências para a prática. Assim como o programa investigado, uma revisão dos objetivos da residência médica na radiologia deveria ocorrer, incorporando, dentro do possível, o compromisso com o treinamento de habilidades relacionadas com a gestão dos recursos humanos e, assim, ampliando o escopo de competências dos futuros radiologistas.

Unitermos: Educação médica; Residência médica; Administração de recursos humanos em saúde; Radiologia; Diagnóstico por imagem.

\section{INTRODUCTION}

Radiology is a diagnostic and therapeutic support specialty involving highly complex procedures, requiring highcost professionals, equipment, facilities and materials, whose activities can only be developed by means of integrated action of multiprofessional teams under the leadership of the radiologist.

* Study developed at Escola Paulista de Medicina - Universidade Federal de São Paulo (EPM-Unifesp), São Paulo, SP, Brazil.

1. Master, Fellow at Escola Paulista de Medicina - Universidade Federal de São Paulo (EPM-Unifesp), São Paulo, SP, Brazil.

2. Teachers, Full Professors, Escola Paulista de Medicina - Universidade Federal de São Paulo (EPM-Unifesp), São Paulo, SP, Brazil.

Mailing Address: Aparecido Ferreira de Oliveira. Centro de Desenvolvimento do Ensino Superior em Saúde da Universidade Federal de São Paulo (Cedess-Unifesp). Rua Pedro de Toledo, 859, Vila Clementino. São Paulo, SP, Brazil, 04039-032. E-mail: aparecidoliveira@ig.com.br.

Received January 24, 2013. Accepted after revision October 4, 2013.
The National Curriculum Guidelines (NCG) ${ }^{(1)}$ for medical education advocate the development of general competencies such as health care, decision making, communication, leadership, administration, management and continued education as follows: "health professionals must be prepared to take on leadership roles with a view on the community's well-being. Leadership involves effective and efficient commitment, responsibility, and empathy, besides decision-making, communication and management skills."

In radiology, multiprofessional teams comprise professionals with specific education and clearly defined roles as follows: physicians, administrators, nurses, technicians and technologists in radiology. With the introduction of digital radiology, processes and workflows have been reorganized, changing work routines and requiring team updating and capacitation with significant benefits to patients; reduction in waiting time required for procedures and results; greater 
productivity; improvement in diagnostic accuracy and possibility of decisions supported by integrated systems and more reliable technologies.

"Nowadays, health care is one of the fields with greater development, constantly incorporating new and complex knowledge, increasingly demanding from professionals the association of high technology with a broad and multi-disciplinary view of their daily tasks" (Romano ${ }^{(2)}$ ).

That reinforces the premise of "need for joint professional actions in health care, regardless of professional category." (Oliveira et al. $\left.{ }^{(3)}\right)$.

Silva et al. ${ }^{(4)}$ explain that the standards for radiologists' education put greater emphasis on the technical aspects rather than on behavioral ones. Those authors emphasize that "the technological and scientific developments in the fields of radiology and imaging diagnosis allow for the professional qualification by means of acquisition of new competences and skills during medical residency and specialization courses, according to the students' aptitudes and expectations, provided that opportunities for the acquisition of such competencies and skills are available."

Having autonomy and being aware of one's role as well as that of other team members, and learning to lead and manage people provide the radiologist with a valuable differential characteristic which the labor market recognizes and which can be taught during residency, an environment filled with human experiences and learning possibilities.

Pinho ${ }^{(5)}$ reinforces such aspects while commenting that "along with the technical skills and competencies, relational abilities that empower the individual to establish interpersonal relationships based on cooperation have also been required."

Thus, preparation to lead the teams with autonomy and awareness of each member's role is a cornerstone of the management of imaging services, a relevant starting point for the development of competencies related to human resources management. Sousa et al. ${ }^{(6)}$ comment that "preceptors should review the proposed objectives of the program and include competencies which supplement the residents' education, besides assisting them in finding mechanisms to acquire such competencies."

In such a context, the following questions should be asked: Has the radiology residency program at Escola Paulista de Medicina - Universidade Federal de São Paulo (EPM-Unifesp) provided the residents with clarity on their degree of autonomy and complexity in the performance of their functions? Are the professionals involved in the daily tasks clearly aware of their roles in the development of the proposed activities? Does residency provide learning on the management of multiprofessional teamwork?

The present study was aimed at investigating, by means of a survey among radiology residents, teachers and preceptors, about the clarity of the residents' degree of autonomy in the development of their functions and on their learning about human resources management in the radiology resi- dency program at EPM/Unifesp, seeking to improve the education of radiologists.

\section{MATERIALS AND METHODS}

The analyzed Radiology Residency Program occurs at a public hospital, with a duration of three years, with 12 positions for the first year (R1), 12 for the second year (R2), and 12 for the third year (R3), counting on a supervising teacher, a coordinator for teaching and research, two leading preceptors, and 11 specialty preceptors (abdomen, head and neck, musculoskeletal system, breast, pediatrics, chest, fetal medicine, emergency, interventional radiology and neurology). All of the Department's staff members, comprising teachers, five collaborating physicians, administrative technicians in education and participants of the professional updating program also participate in residents' education.

The authors have opted for an exploratory study, with both qualitative and quantitative approaches, developed with the residents' population, preceptors and the Program's faculty during the year of 2011 . Five teachers $(55.5 \%$ of the category), 14 preceptors and 27 residents ( $10 \mathrm{R} 1,7 \mathrm{R} 2$ and 10 R3) participated in the study. The study project was duly approved by the Committee for Ethics in Research of Unifesp. The present investigation was part of a master's dissertation presented and approved at EPM-Unifesp.

On the first phase of data collection, 46 individuals ( $75.4 \%$ of the 61 individuals comprising the study sample) responded to an attitude scale in the Likert format comprising 11 statements, out of which three were related to the theme of the present study. Amaro et al. ${ }^{(7)}$ have commented that the Likert scale presents a series of five propositions, one out of which the respondent should select: "strongly agree; agree; neutral; disagree; strongly disagree" with respect to statements related to the investigated object. The data collected, after tabulation and conversion into charts, comprised the fist approach to the object in study.

On the second phase, a qualitative approach was undertaken for deeper analysis of the data. The qualitative investigation is descriptive in nature, where the investigators observe, correlate and describe facts from a given reality, without manipulating such facts, to know the several situations that occur in the analyzed sector. The authors have opted for a case study, which represents a way of investigating or applying a subject at an individual organization. According to Yin $^{(8)}$, the case study investigates a contemporary phenomenon within its real-life context, especially in cases where the limits between the phenomenon and the context are not clearly defined.

Thus, semi-structured three-question interviews were carried out, lasting 10 minutes on average, with a number of participants meeting the criteria of a qualitative investigation, i.e., relevance and recurrence of data and saturation of collected data. That occurred after the 18th interview.

After integral transcription, the data were submitted to a thematic analysis (nuclei of meaning), one of the content analysis techniques, as advocated by Minayo ${ }^{(9)}$ : data order- 
ing, identification and establishment of context units (of which the themes are part of), identification of the recording units (word, phrase or sentence) regarding the analyzed object, and grouping of such units into analysis categories.

\section{RESULTS}

When exposed to the statement "In radiology, the residents clearly know their degree of autonomy and the complexity in the performance of their functions" most $(71 \%)$ teachers, preceptors and residents agreed with the statement, while $15 \%$ disagreed and $14 \%$ did not have an opinion on the subject (Figure 1).

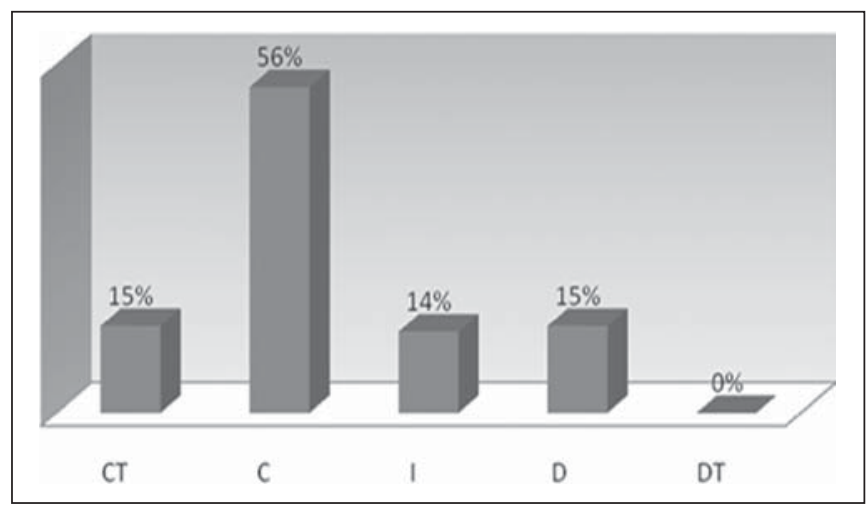

Figure 1. Rate of agreement/disagreement about residents' clarity on their degree of autonomy and complexity in the performance of their functions.

In the deeper analysis phase, the respondents highlighted that residents "are aware of the importance of their role and their autonomy in the medical assistance that they provide" E18) emphasizing that acting in radiology requires an increasing degree of autonomy due to the peculiarities and complexity of the performed tasks. They correlate the development of autonomy with responsibility ("I agree, he knows it is his job, which he cannot delegate to a junior resident or ask his boss to do it, and, along residency period, he acquires the notion of its complexity" - E06) and demands on tasks performance ("he is held accountable for that. He knows that in the US shift he will have to prepare reports and will be responsible for such reports and that in computed tomography he will have to review everything in detail with the preceptor. The responsibility is his alone, and he will be held accountable for that, with a clear knowledge of his degree of responsibility" - E08).

Some respondents highlighted a relative autonomy ("looking at it carefully, he has no autonomy. He has a schedule to meet, and either with or without a lunch break, he must see all those patients" - E14), attributing it to the professional specificities ("the regulation of the activity of each profession is still precarious in our country, and such a schedule depends upon the composition of each group at each service"-E01) and to the complexity of the hospital itself ("we are in a hospital and he doesn't know the relevance of his role in the system's structure" - E14) as limiting factors for the development of autonomy.
When exposed to the statement "In radiology residency, every involved professional has a clear understanding of the individual roles in the development of the proposed activities", only $37 \%$ of the respondents agreed (Figure 2).

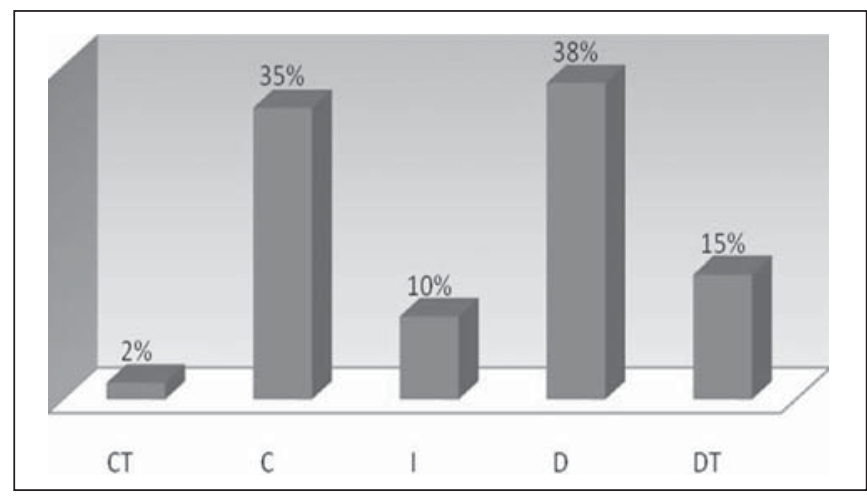

Figure 2. Rate of agreement/disagreement on whether all involved professionals have clarity of their roles in the development of proposed activities.

In the qualitative interviews, some teachers, preceptors and residents reinforced such finding: "not every professional, I disagree, there are some professionals who do not clearly know their roles" - E02) and ("neither residents, nor the professionals have a clear notion of their functions and how doing a good job or not, affects the service"- E14).

Among the answers, two categories were found, which, even emphasizing the limitations, point out opportunities to minimize such difficulty: the need for discussion and supervision ("it is really a matter of supervision. There should exist more supervisors in each sector, each professional should be supervised more closely in their tasks" - E03) and of specific training for teamwork ("not everyone has such clarity on their roles, because there is not an in-depth and elaborated training on that subject" - E16).

As the respondents were exposed to the statement: "In radiology, the resident has the opportunity of learning to manage a multiprofessional teamwork", $48 \%$ of the teachers, preceptors and residents disagreed, demonstrating the need for such training during residency ( $13 \%$ of the respondents did not have an opinion on the matter and 39\% agreed with the statement) (Figure 3).

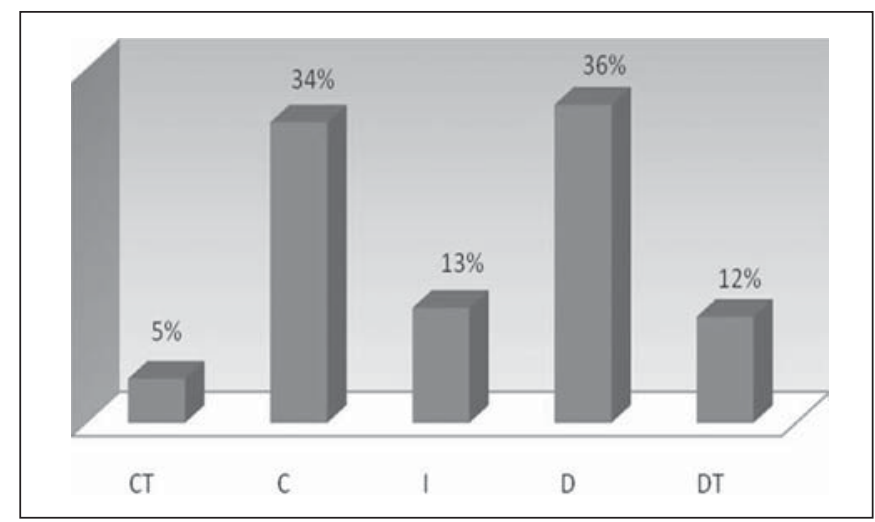

Figure 3. Rate of agreement/disagreement on the opportunity of learning to manage multiprofessional teamwork. 
In the qualitative phase of data collection, the respondents reinforced their disagreement, declaring that there are more limitations than opportunities for such learning ("we do not learn how to work with a multiprofessional team" - E11).

The thematic analysis of the responses allowed the authors to observe the following response categories: the routine restricted to the isolate practice in the medical reporting rooms ("we frequently work alone. It is you, your colleagues and the preceptors in the medical reporting rooms" E03), the absence of emphasis on the program ("neither the opportunity to learn, nor to manage multiprofessional teamwork - we are not focused on that, and such a theme is not even approached" - E17), the development of diversified activities with little interaction among the areas ("the services in residency are quite compartmentalized"- E17) and the lack of a previous multiprofessional interaction culture ("we do not have the culture of multiprofessional team management" - E17).

In spite of the limitations, one recognizes that there are some opportunities for such learning ("there is a chance to further explore the subject, as it is a part of the professional life in this residency phase" - E13), whether it in the daily interaction between residents and teams ("we do have the opportunity to work with multiprofessional teams, with technicians and nursing personnel" - E05) or in the favorable environment of a school hospital ("here we do learn well on how to manage a multiprofessional teamwork, as this is a school hospital" - E14).

\section{DISCUSSION}

The Comissão Nacional de Residência Médica (CNRM) (National Commission of Medical Residency), by its Resolution No. 4 dated July 12, $2010^{(10)}$, establishes that "the appropriate way to provide training for the resident physician aiming at an appropriate education with development of autonomy and independence required for the future professional life is in service, under the preceptor's supervision, in a Medical Residency Program accredited by CNMR)".

Fleury-Teixeira et al. ${ }^{(11)}$ clarified that "autonomy (auto $=$ self, nomos = law) immediately leads to the thought of freedom and capability of active exercise of oneself, of the free determination of individuals on their own actions and to the possibilities and capabilities to build their own paths in life".

Machado et al. ${ }^{(12)}$ have commented that the education of health professionals must provide "autonomy and emancipation as he is a historical and social individual capable of proposing decisions on health for himself, his family and the community".

The development of the future radiologist's autonomy is directly related to the clarity in the definition of roles (the radiologist's and of the other members of the team) and capability to manage human resources with whom the radiologist will work with.

Oliveira et al. ${ }^{(3)}$ highlight that "when involved with the qualification of the professionals, health institutions can act as facilitators in the process, by acting in a collaborative and committed manner", as this is the ideal moment for the resident to learn on leading teams and to define roles and tasks.

The importance of leadership in the context of human resources management also lies on understanding and overcoming the lack of integration, the poor interaction and the reduced spirit of collectiveness among members of the team, besides role conflicts and power disputes, affecting both the individual and the multidisciplinary group performances.

Feuerwerker et al. ${ }^{(13)}$ comment that: "in a hospital, care depends on the integration of various professionals' work... Thus, a complex network of acts, procedures, routines, knowledge, in a process of complementation and dispute, make up health care".

The learning of leadership begins with the mastery of the technical field complemented by relational aspects. Some critical points in the development of leadership are understandable at the different phases in residency, starting with the introduction, insertion and integration into existing teams. Leadership capabilities only develop over time, by means of the consolidation of knowledge, and establishment of autonomy at the end of residency, depending upon individual maturity and interest.

Gunderman et al. ${ }^{(14)}$, analyzing the teaching of radiology in medical schools, say that it is important to develop a curricular plan including new and specific teaching opportunities. The teaching of human resources management must take advantage of the multiprofessional and interdisciplinary environment, adding the experience from teachers, preceptors, radiologists, administrators, nursing professionals and radiology technicians and technologists.

\section{CONCLUSIONS}

The present study has demonstrated that most respondents agree that residency provides the residents with clarity in relation to the degree of autonomy to face complexities, in spite of room for improvements in the program (disagreement of $15 \%$ of the respondents). The learning deficiencies on team management compromise the development of leadership skills, an important subject to be explored in the curricula of such programs. Sectorized activities, isolation in medical reporting rooms and lack of previous multiprofessional culture hinder such process.

The lack of a clear understanding by some professionals on their roles in developed activities might generate conflicts and distancing among team members, hindering collective actions and the necessary integration for a better work development.

The authors understand that the residency programs should promote the inclusion of lectures, meetings and supervised joint discussions on actions, team member roles and functions, emphasizing the relevance of multiprofessional acting, thus better preparing the future radiologist for the professional practice. Thus, the programs would be involving residents as "trainees who teach while learning" in a 
constant, evolving process of professional education and development.

\section{REFERENCES}

1. Brasil. Ministério da Educação. Conselho Nacional de Educação. Câmara de Educação Superior. Resolução CNE/CES n4, de 01/ $11 / 2001$. Institui diretrizes curriculares nacionais do curso de graduação em medicina. [acessado em 11 de dezembro de 2012]. Disponível em: http://portal.mec.gov.br/cne/arquivos/pdf/CES04.pdf.

2. Romano VF. Educação a distância na qualificação profissional em saúde. RECIIS. 2007;1:247-51.

3. Oliveira NA, Thofehrn MB, Cecagno D, et al. Especialização em projetos assistenciais de enfermagem: contribuições na prática profissional dos egressos. Texto Contexto Enferm. 2009;18:697-704.

4. Silva GCC, Koch HA, Sousa EG. O perfil do médico em formação em radiologia e diagnóstico por imagem. Radiol Bras. 2007;40:99_ 103.

5. Pinho MCG. Trabalho em equipe de saúde: limites e possibilidades de atuação eficaz. Ciências e Cognição. 2006;8:68-87.

6. Sousa EG. Koch HA. O residente ideal em radiologia e diagnóstico por imagem. Radiol Bras. 2004;37:455-6.

7. Amaro A, Póvoa A, Macedo L. A arte de fazer questionários. Porto, Portugal: Faculdade de Ciências da Universidade do Porto; 2004/
2005. [acessado em 14 de abril de 2012]. Disponível em: nautilus.fis. uc.pt/cec/esjf/wp-content/uploads/2009/11/elab_quest_quimica_ up.pdf.

8. Yin RK. Estudo de caso: planejamento e métodos. $2^{\mathrm{a}}$ ed. Porto Alegre: Bookman; 2001.

9. Minayo MCS. O desafio do conhecimento. Pesquisa qualitativa em saúde. São Paulo: Hucitec; 1999.

10. Brasil. Ministério da Educação. Conselho Nacional de Residência Médica. Resolução MEC/SESu/CNRM nº 4, de 12 de julho de 2010. Proíbe o plantão de sobreaviso para médicos residentes no âmbito da residência médica. [acessado em 13 de fevereiro de 2013]. Disponível em: http://portal.mec.gov.br/index.php?option=com_content\& view $=$ article $\&$ id $=13079 \&$ Itemid $=506$.

11. Fleury-Teixeira P, Vaz FAC, Campos FCC, et al. Autonomia como categoria central no conceito de promoção de saúde. Ciênc Saúde Coletiva. 2008;13(Supl 2):2115-22.

12. Machado MFAS, Monteiro EMLM, Queiroz DT, et al. Integralidade, formação de saúde, educação em saúde e as propostas do SUS - uma revisão conceitual. Ciênc Saúde Coletiva. 2007;12:335-42.

13. Feuerwerker LCM, Cecílio LCO. O hospital e a formação em saúde: desafios atuais. Ciênc Saúde Coletiva. 2007;12:965-71.

14. Gunderman RB, Siddiqui AR, Heitkamp DE, et al. The vital role of radiology in the medical school curriculum. AJR Am J Roentgenol. 2003; 180: 1239-42. 